\title{
Macroscopic Study of the Isthmus of the Thyroid Gland in Bangladeshi People: A Postmortem Study
}

\author{
Fakhrul Amin Mohammad Hasanul Banna ${ }^{1}$, Zakia Sultana ${ }^{2}$ \\ Received: April 16, 2016 Accepted: December 3, 2016 \\ doi: http://dx.doi.org/10.3329/jemc.v7i1.30745
}

\begin{abstract}
Background: The position and size of isthmus of thyroid gland varies considerably in human with age, sex, physiologic state, race and geographical location and sometimes the isthmus may be absent. So this study was designed to find out the macroscopic differences in isthmus of thyroid gland of different age and sex groups in Bangladeshi people. Objective: To record the macroscopic characteristics of isthmus of thyroid gland with advancing age in both sexes with a view to help establishing normal standard of Bangladeshi people. Materials and Methods: This descriptive cross-sectional study was carried out on 54 autopsied human thyroid glands aged 5 to 65 years. Thyroid glands were collected from unclaimed dead bodies autopsied in the morgue of Sylhet M. A. G. Osmani Medical College, Sylhet. The collected specimens were divided into groups - A (20 years and below), B (21 to 50 years) and $C$ (50 years and above). All specimens were examined morphologically by careful gross dissection method. Results: The isthmus was absent in $5.56 \%$

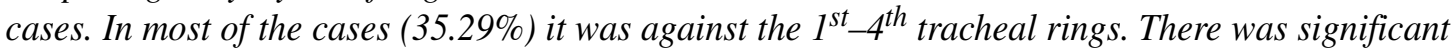
difference in length between Group A and Group $C(p<0.05)$ and in breadth between Group A and Group $C$ and between Group $B$ and Group $C(p<0.05)$. No significant difference was found in length, breadth and thickness of isthmus of the thyroid gland between males and females.

Conclusion: The presence or absence, positional change and variation in gross dimension of isthmus of thyroid gland were evident in human. The macroscopic difference was found with increasing age but not with sex.
\end{abstract}

Key words: Thyroid gland; Isthmus; Macroscopic

J Enam Med Col 2017; 7(1): 15-19

\section{Introduction}

The thyroid is the earliest endocrine glandular structure to appear in mammalian development that influences many organs of the body and plays an important role in the metabolic activities of human and other animals. Leonardo da Vinci probably found it by about 1500, and Vesalius definitely knew about it by 1543 . By the early 1600 s, anatomists definitely identified the thyroid gland in humans. ${ }^{1}$

The thyroid gland is a horseshoe-shaped mass clasping the upper part of the trachea. ${ }^{2}$ It consists of two symmetrical lobes united by constricted isthmus. The isthmus is a variable band of glandular tissue that unites the lower parts of the right and left lobes, and lies in front of the second, third and fourth tracheal rings. The isthmus varies greatly and sometimes is absent. ${ }^{3,4}$ Agenesis of the thyroid isthmus can also be defined as the complete and congenital absence of isthmus. ${ }^{5}$ The basic mechanism of agenesis of isthmus can be attributed to developmental anomalies. Available literature suggests that chromosome 22 has a major role in the thyroid gland development. ${ }^{6}$ A pyramidal lobe, of frequent occurrence but of variable size, extends upward from the isthmus or from the junction of the isthmus and one of the lateral lobes, usually the left ${ }^{7}$ and is connected to the thyroid cartilage and hyoid bone. ${ }^{8}$ In addition to the pyramidal lobe, there may be a

1. Associate Professor, Department of Anatomy, Enam Medical College, Savar, Dhaka

2. Professor, Department of Anatomy, Sylhet M. A. G. Osmani Medical College, Sylhet

Correspondence Fakhrul Amin Mohammad Hasanul Banna, Email: mhasanulbanna@yahoo.com 
fibromuscular band known as the levator glandulae thyroideae which usually replaces the upper part of the pyramidal lobe. ${ }^{9}$ However, morphological study of thyroid isthmus bears a great importance. We have only few studies on human organs in Bangladesh, especially in their anatomical variation in site, size and gross dimensions in comparison to those of the Western population.

\section{Materials and Methods}

This descriptive cross-sectional study was conducted in the Department of Anatomy, Sylhet M. A. G. Osmani Medical College (SOMC) from July 2006 to June 2007. The research work was approved by the Ethical Review Committee of Sylhet M. A. G. Osmani Medical College, Sylhet.

This study was done on 54 postmortem human thyroid glands collected from individuals of both sexes (male 43 and female 11) aged from 5 to 65 years at the autopsy laboratory of Department of Forensic Medicine, SOMC. Age and sex of cadavers were collected from records in the register book. All the samples were collected from medicolegal cases excluding hanging, poisoning, any cutting or crushing injury to the thyroid gland and known case of thyroid disease. The collected samples were fixed in $10 \%$ formal saline solution. Dissection was carried out to expose the thyroid glands. The thyroid gland was examined for the following variables - a) Presence or absence of isthmus, b) Posterior relation of isthmus, c) Length, breadth and thickness of isthmus. Among them isthmus was found in 51 cases. The samples having the isthmus $(\mathrm{n}=51)$ were divided into three age groups - Group A (20 years and below), Group B (21 to 50 years) and Group C (50 years and above). ${ }^{10}$

\section{Measurement of length, breadth and thickness of isthmus}

The length of the isthmus was measured transversely at its superior limit, the middle part and the inferior limit with the help of a scale. The mean measurement was recorded for further use. The breadth of the isthmus was measured from superior to inferior border with a scale. Three measurements were taken at its right end, left end and middle part. The mean value was recorded as breadth of the isthmus. The thickness of the isthmus was measured anteroposteriorly at its two ends and middle part with a slide calipers. The mean value was recorded as thickness of the isthmus. ${ }^{11}$

Statistical analyses were done by unpaired Student " $t$ " test and one way ANOVA test using SPSS 12.0 version.

\section{Results}

In this study it was observed that out of 54 thyroid glands 3 (5.56\%) had no isthmus. In 18 (35.29\%) cases the isthmus was related to $1^{\text {st }}, 2^{\text {nd }}, 3^{\text {rd }}$ and $4^{\text {th }}$ tracheal rings posteriorly. Table I shows the posterior relation of isthmus of the thyroid gland. There is significant difference regarding posterior relation of isthmus in relation to tracheal rings. Table II shows the length, breadth and thickness of isthmus of the thyroid gland in different age groups of study population.

Table I: Posterior relation of isthmus with tracheal rings and cricoids cartilage

\begin{tabular}{|c|c|c|c|c|}
\hline \multirow{2}{*}{ Tracheal rings/Cricoid cartilage } & \multicolumn{3}{|c|}{ Number of isthmus } & \multirow{2}{*}{ Total } \\
\hline & Group A & Group B & Group C & \\
\hline $1-2$ & 0 & 3 & 0 & $3(5.56 \%)$ \\
\hline $1-3$ & 3 & 5 & 0 & $8(15.69 \%)$ \\
\hline $1-4$ & 7 & 9 & 2 & $18(35.29 \%)$ \\
\hline $1-5$ & 1 & 10 & 2 & $13(25.49 \%)$ \\
\hline $1-6$ & 0 & 1 & 0 & $1(1.96 \%)$ \\
\hline $1-7$ & 0 & 0 & 1 & $1(1.96 \%)$ \\
\hline $2-4$ & 0 & 0 & 1 & $1(1.96 \%)$ \\
\hline $2-5$ & 0 & 1 & 0 & $1(1.96 \%)$ \\
\hline Cricoid cartilage $-4^{\text {th }}$ & 1 & 1 & 0 & $2(3.92 \%)$ \\
\hline Cricoid cartilage- $5^{\text {th }}$ & 1 & 0 & 0 & $1(1.96 \%)$ \\
\hline Cricoid cartilage $-6^{\text {th }}$ & 1 & 1 & 0 & $2(3.92 \%)$ \\
\hline Absent isthmus & 0 & 3 & 0 & $3(5.56 \%)$ \\
\hline
\end{tabular}


Table II: Length, breadth and thickness of isthmus of the thyroid gland in different age groups

\begin{tabular}{|l|c|c|c|c|c|c|}
\hline \multirow{2}{*}{ Groups } & \multicolumn{2}{|c}{ Length $(\mathrm{cm})$} & \multicolumn{2}{c|}{ Breadth $(\mathrm{cm})$} & \multicolumn{2}{c|}{ Thickness $(\mathrm{cm})$} \\
\hline & Mean (Range) & P values & Mean (Range) & P values & Mean (Range) & P values \\
\hline A (n=13) & $1.25 \pm 0.54$ & A vs B & $1.53 \pm 0.60$ & A vs B & $0.56 \pm 0.22$ & A vs B \\
& $(0.6-2.5)$ & $>0.05$ & $(0.97-3.07)$ & $>0.05$ & $(0.33-1.07)$ & $>0.05$ \\
\hline B (n=23) & $1.41 \pm 0.64$ & B vs C & $1.68 \pm 0.52$ & B vs & $0.50 \pm 0.19$ & B vs C \\
& $(0.53-2.6)$ & $>0.05$ & $(0.66-2.6)$ & C <0.05 & $(0.23-0.93)$ & $>0.05$ \\
\hline C (n=15) & $1.80 \pm 0.64$ & A vs C & $2.02 \pm 0.52$ & A vs C & $0.55 \pm 0.13$ & A vs C \\
& $(0.83-2.97)$ & $<0.05$ & $(1.5-2.37)$ & $<0.05$ & $(0.27-0.77)$ & $>0.05$ \\
\hline
\end{tabular}

The post-Hoc option of analysis of variance (ANOVA) test was done to compare each group from other group for each variable. The difference was considered to be significant statistically at $5 \%$ level (i.e. $\mathrm{p}<0.05$ ).

Table III: Length, breadth and thickness of isthmus of the thyroid gland in male and female

\begin{tabular}{|l|c|c|c|c|c|c|}
\hline \multirow{2}{*}{ Sex } & \multicolumn{2}{|c|}{ Length $(\mathrm{cm})$} & \multicolumn{2}{c|}{ Breadth $(\mathrm{cm})$} & \multicolumn{2}{c|}{ Thickness $(\mathrm{cm})$} \\
\hline & Mean (Range) & P values & Mean (Range) & P values & Mean (Range) & P values \\
\hline Male $(\mathrm{n}=40)$ & $1.50 \pm 0.65$ & & $1.65 \pm 0.46$ & & $0.51 \pm 0.17$ & \\
& $(0.57-2.97)$ & Male & $(0.66-2.37)$ & Male & $(0.23-1.07)$ & Male \\
\hline Female $(\mathrm{n}=11)$ & $1.36 \pm 0.65$ & vs & $1.98 \pm 0.66$ & vs & $0.57 \pm 0.23$ & vs \\
& $(0.53-2.7)$ & Female & $(0.97-3.07)$ & Female & $(0.27-0.93)$ & Female \\
\hline Total $(\mathrm{n}=51)$ & $1.46 \pm 0.64$ & $>0.05$ & $1.72 \pm 0.52$ & $>0.05$ & $0.53 \pm 0.19$ & $>0.05$ \\
& $(0.53-2.97)$ & & $(0.66-3.07)$ & & $(0.23-1.07)$ & \\
\hline
\end{tabular}

Unpaired Student " $\mathrm{t}$ " test was done to analyze data

In this study it was found that the average length of the isthmus of the thyroid gland was $1.25 \pm 0.54$, $1.41 \pm 0.64$ and $1.80 \pm 0.64 \mathrm{~cm}$ in Groups A, B and $\mathrm{C}$ respectively. The mean length of isthmus of the thyroid gland was highest in Group $\mathrm{C}$ and lowest in Group A. There was significant difference between Group A vs Group C ( $<<0.05)$.

In this study the average breadth of the isthmus of the thyroid gland was $1.53 \pm 0.60,1.68 \pm 0.52$ and $2.02 \pm 0.52 \mathrm{~cm}$ in Groups A, B and C respectively. There was significant difference between Group A vs Group C and B vs C ( $<<0.05)$.

In this study the average thickness of the isthmus of the thyroid gland was $0.56 \pm 0.22,0.50 \pm 0.19$ and $0.55 \pm 0.13 \mathrm{~cm}$ in Groups A, B and C respectively. There was no significant difference among the groups. There was no significant difference between males and females regarding length, breadth and thickness of isthmus of the thyroid gland (Table III)

\section{Discussion}

In the present study, it was found that $5.56 \%$ thyroid gland had no isthmus. This observation can be compared with study done by Enayetullah ${ }^{11}$, Marshall ${ }^{12}$, Ranade et $\mathrm{al}^{13}$, Nurunnabi et $\mathrm{al}^{14}$, Dixit et $\mathrm{al}^{15}$, Prakash et $\mathrm{al}^{16}$, Tanriover et $\mathrm{al}^{17}$, Kulkarni et $\mathrm{al}^{18}$, Muktyaz et $\mathrm{al}^{19}$ and Veerahanumaiah et $\mathrm{al}^{20}$ (Table IV).

Table IV: Comparison of absence of isthmus in other studies with that in this study

\begin{tabular}{|l|c|c|}
\hline Authors and year of study & Sample size & of absence of isthmus \\
\hline Marshall CF (1891) & 60 & 10 \\
\hline Enayetullah (1995) & 50 & 4 \\
\hline Ranade et al (2008) & 105 & 33 \\
\hline Nurunnabi ASM (2008) & 73 & 18.8 \\
\hline Dixit et al (2009) & 41 & 14 \\
\hline Prakash et al (2011) & 70 & 8.57 \\
\hline Tanriover et al (2012) & 90 & 2.22 \\
\hline Veena Kulkarni et al (2011) & 20 & 10 \\
\hline Muktyaz et al (2013) & 56 & 12.5 \\
\hline Veerahanumaiah et al (2014) & 89 & 9 \\
\hline This study (2007) & 54 & 5.56 \\
\hline
\end{tabular}


In this study, the isthmus was posteriorly related with $1^{\text {st }}, 2^{\text {nd }}, 3^{\text {rd }}$ and $4^{\text {th }}$ tracheal rings in $35.29 \%$ cases. Francis $^{2}$, Sinnatamby ${ }^{3}$, Kelly et $\mathrm{al}^{4}$, Woodurne ${ }^{7}$, Basmajian \& Slonecker ${ }^{8}$, Kanagasuntheram et $\mathrm{al}^{9}$, Gardner et $\mathrm{al}^{21}$ and Snell ${ }^{22}$ described that the position of isthmus of thyroid gland lies against $2^{\text {nd }}$ to $4^{\text {th }}$ tracheal rings, which was similar to the findings in present study. Decker ${ }^{23}$, Hoyes \& Karshaw ${ }^{24}$, Moore \& Dalley $^{25}$ and Pollock ${ }^{26}$ described that isthmus of thyroid gland lies against $2^{\text {nd }}$ and $3^{\text {rd }}$ tracheal rings and DeGroot $^{27}$ described that it lies against $1^{\text {st }}$ and $2^{\text {nd }}$ tracheal rings. Enayetullah ${ }^{11}$ found that isthmus was absent in $4 \%$ cases. In his study the isthmus was related posteriorly to $2^{\text {nd }}$ to $4^{\text {th }}$ tracheal rings in $72 \%$ cases. ${ }^{11}$ Similar result was also observed by Begum $^{28}$ in Bangladeshi people. In our study, we have seen the isthmus of thyroid gland posteriorly related also with cricoid cartilage to $4^{\text {th }} / 5^{\text {th }} / 6^{\text {th }}$ tracheal rings in few cases. But other authors did not show such types of relation.

In the present study the average length of the isthmus of the thyroid gland was $1.46 \pm 0.64 \mathrm{~cm}$. The mean length of isthmus of the thyroid gland in male was $1.50 \pm 0.65$ $\mathrm{cm}$ and in female was $1.36 \pm 0.65 \mathrm{~cm}$. Standring et al ${ }^{29}$ described the length of isthmus of thyroid gland is 1.25 $\mathrm{cm}$ and DeGroot ${ }^{27}$ described it 1.2 to $2 \mathrm{~cm}$ which are similar to the present study. Similar result was also observed by Enayetullah ${ }^{11}$ and Begum ${ }^{28}$. Hoyes \& Karshaw $^{24}$ described it $2 \mathrm{~cm}$ which was higher than findings in the present study.

In the present study the average breadth of the isthmus of the thyroid gland was $1.72 \pm 0.52 \mathrm{~cm}$. The mean breadth of isthmus of the thyroid gland in male was $1.65 \pm 0.46 \mathrm{~cm}$ and in female was $1.98 \pm 0.66 \mathrm{~cm}$. Pollock ${ }^{26}$ described that the breadth of isthmus of thyroid gland is $1.3 \mathrm{~cm}$ and Standring et $\mathrm{al}^{29}$ described it $1.25 \mathrm{~cm}$ which are lower than the findings in present study. Enayetullah ${ }^{11}$, Hoyes \& Karshaw $^{24}$, DeGroot ${ }^{27}$ and Begum ${ }^{28}$ found it $2 \mathrm{~cm}$ which is similar to finding in the present study.

In the present study the average thickness of the isthmus of the thyroid gland was $0.53 \pm 0.19 \mathrm{~cm}$. The mean thickness of isthmus of the thyroid gland in male was $0.51 \pm 0.17 \mathrm{~cm}$ and in female was $0.57 \pm 0.23 \mathrm{~cm}$. Hoyes \& Karshaw $^{24}$ described the breadth of isthmus of thyroid gland is 0.2 to $0.6 \mathrm{~cm}$ which is similar to the findings in the present study. Similar results were also found by Enayetullah ${ }^{11}$ and Begum ${ }^{28}$.
The nature of specimens studied and the areas where studies are carried out, effect of different goiter zones, age, sex and race of population studied can contribute to the anatomical variations of the thyroid gland found in different reports by various authors.

In this study, the presence or absence, positional change and variation in gross dimension of isthmus of thyroid gland were evident in humans. The macroscopic difference was found with increasing age but not with sex. This study will also help in minimizing complications of thyroid surgery and tracheostomy. We would like to recommend further studies with larger samples and high technical support.

\section{Acknowledgement}

We are thankful to the teaching and nonteaching staff of departments of Anatomy and Forensic Medicine, Sylhet M. A. G. Osmani Medical College, Sylhet for their great help during collection of specimens, finding age and sex from registered book and also for giving time and space during dissection and observing specimens.

\section{References}

1. Sawin CT. The heritage of the thyroid. In: Braverman LE, Utiger RD (eds). Werner \& Inbar's the thyroid: a fundamental and clinical text. $8^{\text {th }}$ edn. Philadelphia: Lippincott Williams and Wilkins, 2000: 3-6.

2. Francis CC. The endocrine system. In: Introduction to human anatomy. $6^{\text {th }}$ edn. Saint Louis: The CV Mosby Company, 1973: 251-253.

3. Sinnatamby CS. Head and neck and spine - triangles of neck. In: Last's anatomy: regional and applied. $10^{\text {th }}$ edn, Edinburgh: Churchill Livingstone, 1999: 324-336.

4. Kelly DE, Wood RL, Enders AC. The endocrine glands. In: Bailey's textbook of microscopic anatomy, $18^{\text {th }}$ edn. Baltimore: Williams and Wilkins, 1984: 794-804.

5. Pastor VJ, Gil VJ, De Paz Fernandez FJ, Cachorro MB. Agenesis of thyroid isthmus. Eur J Anat 2006; 10: 83-84.

6. Gangbo E, Lacombe D, Alberti EM, Taine L, Saura R, Carles D. Trisomy 22 with thyroid isthmus agenesis and absent gall bladder. Genet Couns 2004; 15: 311-315.

7. Woodburne RT. The head and neck. In: Essentials of human anatomy. $5^{\text {th }}$ edn. New York: Oxford University Press, 1973: 153-157.

8. Basmajian JV, Slonecker CE. Head and neck. In: Grant's method of anatomy. $11^{\text {th }}$ edn. Baltimore: Williams and Wilkins, 1989: 503-504.

9. Kanagasuntheram R, Sivanandasingham P, Krishnamurti A. Head and neck. In: Anatomy: regional, functional and clinical. Singapore: PG Publishing Pte. Ltd., 1987: 557-560. 
10. Brown RA, Al-Moussa M, Beck JS. Histometry of normal thyroid in man. J Clinical Pathology 1986; 39(1): 475-482.

11. Enayetullah M. Gross and histomorphological study of thyroid and parathyroid glands in Bangladeshi people [M Phil thesis]. Dhaka: Institute of Postgraduate Medicine \& Research (IPGMR), University of Dhaka; 1996.

12. Marshall CF. Variations in the form of the thyroid gland in man. Jour Anat and Phys 1895; 29: 234-239.

13. Ranade AV, Rai R, Pai MM, Nayak SR, Prakash, Krishnamurthy A et al. Anatomical variations of the thyroid gland: possible surgical implications. Singapore Med J 2008; 49: 831-834.

14. Nurunnabi ASM, Mahbub S, Perven HA, Ara S. Morphometric study of the isthmus of the thyroid gland in Bangladeshi cadaver. Nepal J Med Sci 2013; 2(2): 81-84.

15. Dixit D, Shilpa MB, Harsh MP, Ravishankar MV. Agenesis of isthmus of thyroid gland in adult human cadavers: a case series. Cases J 2009; 2: 6640.

16. Prakash, Rajini T, Ramachandran A, Savalgi GB, Venkata SP, Mokhasi V. Variations in the anatomy of the thyroid gland: clinical implications of a cadaver study. Anat Sci Int (Japan Assoc Anat) 2011; 87(1): 45-49.

17. Tanriover O, Comunoglu N, Eren B, Comunoglu C, Turkmen $\mathrm{N}$, Bilgen $\mathrm{S}$ et al. Morphometric features of the thyroid gland: a cadaveric study of Turkish people. Via Medica 2012; 70(2): 103-108.

18. Kulkarni V, Sreepadma S, Deshpande SK. Morphological variations of the thyroid gland. Medica Innovatica 2012; 1(2): 35-38.

19. Muktyaz H, Birendra Y, Dhiraj S, Arun SK. Anatomical variations of thyroid gland and its clinical significance in North Indian population. Glob J Biol Agricul Health Sci 2013; 2(2): 12-16.
20. Veerahanumaiah S, Dakshayani KR, Menasinkai SB. Morphological variations of the thyroid gland. International Journal of Research in Medical Sciences 2015; 3(1): 53-57.

21. Gardner E, Gray DJ, O'Rahilly R. The Neck. In: Anatomy: a regional study of human structure. $5^{\text {th }}$ edn. Philadelphia: WB Saunders company, 1986: 696-699.

22. Snell RS. The head and neck. In: Clinical anatomy for medical students. $7^{\text {th }}$ edn. Philadelphia: Lippincott Williams and Wilkins, 2004: 719-922.

23. Decker GAG, Plessis DJD. Thyroid, thymus and parathyroid. In: Lee McGregor's synopsis of surgical anatomy, $12^{\text {th }}$ edn. Bombay: Varghese Publishing House, 1986: 198-207.

24. Hoyes AD, Kershaw DR. Anatomy and development of the thyroid gland. Ear Nose and Throat J 1985; 64: 318-333.

25. Moore KL, Dalley AF II. Neck. In: Clinically oriented anatomy. $4^{\text {th }}$ edn. Philadelphia: Lippincott Williams and Wilkins, 1999: 1030-1037.

26. Pollock WF. Surgical anatomy of the thyroid and parathyroid glands. The Surgical Clinics of North America 1964; 44(5): 1161-1173.

27. Thyroid gland: anatomy and development. In: DeGroot LJ, Jameson JL (eds). Endocrinology. $4^{\text {th }}$ edn. Philadelphia: WB Saunders Company, 2001: 1268-1277.

28. Begum M. Gross and histomorphological study of human postmortem thyroid gland in Bangladeshi people [M Phil thesis], Dhaka: Sir Salimullah Medical College, University of Dhaka; 2004.

29. Thyroid gland - endocrine system. In: Standring S, Ellis H, Healy JC, Johnson D, Williams (eds). Gray's anatomy: the anatomical basis of clinical practice. $39^{\text {th }}$ edn. New York: Churchill Livingstone, 2005: 560-566. 